\title{
In situ Study of the Glycolytic Pathway in Saccharomyces cerevisiae*
}

\author{
Marcelino Bañuelos ** and Carlos Gancedo*** \\ Instituto de Enzimologia del C.S.I.C., Facultad de Medicina de la Universidad Autónoma, Madrid-34, Spain
}

\begin{abstract}
The problem of the influence of protein concentration on the kinetic parameters of enzymes has been approached studying the glycolytic enzymes from Saccharomyces cerevisiae in permeabilized cells (in situ). 2. The values of $K_{\mathrm{m}}$ and $V_{\max }$ for the different enzymes were essentially the same in dilute solutions of protein and in concentrated ones (in situ) except in the case of enolase where some differences were observed. 3. Functioning of the whole glycolytic pathway was compared in situ and in vitro measuring the rate of the fermentation of glucose. The rate of fermentation in situ was two fold higher than in vitro and the lag before active fermentation was also much shorter. 4. An unidentified phosphorylated compound, possibly polyphosphate, accumulates during the fermentation of glucose under in situ conditions.
\end{abstract}

Key words: Saccharomyces cerevisiae - Glycolytic pathway - Fermentation rate - Protein concentration - Kinetic parameters - Glycolytic enzymes.

Differences in the kinetic behaviour of several enzymes depending on the concentration of protein in the assay have been clearly documented (Srere, 1967; Frieden and Colman, 1967; Hulme and Tripton, 1971; Hofer, 1971). Owing to technical reasons the concentration of protein employed in the conventional enzymatic tests is in general of the order of a thousand-fold lower than that found in the cells. This great dilution factor might affect the protein-protein interactions of enzymes both with molecules of the same kind (homologous in-

\footnotetext{
* A preliminary account of these results was presented at the Fourth International Symposium of Metabolic interconversion of enzymes, Israel (1975)

** Present address: University of Michigan, Division of Biological Sciences, Ann Arbor, MI48109, U.S.A.

*** To whom offprint requests should be addressed
}

teractions) and with other proteins (heterologous interactions) (Hess and Boiteux, 1972) and introduce artifacts in the measurement of some properties.

In order to study the effect of the concentration of protein on the kinetic parameters of a variety of enzymes we decided to examine the behaviour of the glycolytic enzymes from yeast using the in situ approach, a technique that allows the assay of enzymes in conditions similar to those prevailing in vivo with regard to concentration and interaction of macromolecules (Reeves and Sols, 1973; Serrano et al., 1973). Data obtained with the in situ approach have explained in some cases the in vivo behaviour of certain enzymatic systems while the data from conventional methods failed to do so (Kornberg and Reeves, 1972; Reeves and Sols, 1973). The glycolytic pathway was chosen because in yeast the glycolytic enzymes represent about $65 \%$ of the total soluble protein (Hess et al., 1969; Hess, 1973) and this could favour the existence of protein-protein complexes. The importance of the pathway in generai biochemistry, the availability of information on its enzymes and the involvement in it of several allosteric enzymes also weighed in our choice.

Our results show that in general values obtained by conventional methods do not differ from those obtained at physiological protein concentration.

\section{Material and Methods \\ Organism and Growth}

Saccharomyces cerevisiae CJM 13 (originally provided as S. cerevisiae 1714-24 A by Dr. D. C. Hawthorne, Washington University, U.S.A.) was used along this work. Growth took place in a minimal salts medium (Olson and Johnson, 1949) substituting $\mathrm{NaCl}(0.25 \mathrm{~g} / \mathrm{l})$ for sodium citrate and adjusting the $\mathrm{pH}$ to 5.5 with $5 \mathrm{M} \mathrm{NaOH}$. As carbon and energy sources $2 \%$ glucose was used. The yeasts were shaken at $30^{\circ} \mathrm{C}$, harvested by centrifugation at the middle of the exponential phase of growth (optical density around 0.5 at $660 \mathrm{~nm}$ ) and washed with distilled water. 


\section{Permeabilization of the Yeast and Preparation of Extracts}

Permeabilization was performed essentially as described by Serrano et al. (1973) in a buffer of the following composition: $75 \mathrm{mM}$ imidazole, $0.1 \mathrm{M} \mathrm{KCl}, 10 \mathrm{mM} \mathrm{MgCl}$, $5 \mathrm{mM} 2$ mercaptoethanol $\mathrm{pH} 7$.

Extracts were obtained grinding the yeasts in the cold with three times their weight of alumina and extracting the paste with 3 volumes of the buffer described above. After centrifugation at $27000 \times \mathrm{g}$ for $15 \mathrm{~min}$, the supernatants were used for the assays. Assays were completed within $3-5 \mathrm{~h}$ after permeabilization or extraction of the cells.

\section{Assay of Enzymes}

Enzymes were assayed by conventional methods coupling the principal reaction to the oxidation or reduction of pyridine nucleotides and following it at $340 \mathrm{~nm}$. Unless otherwise stated the reactions were carried out at $30^{\circ}$ in a buffer of the following composition: $40 \mathrm{mM}$ 2-(N-morpholino)ethane sulfonic acid, $0.1 \mathrm{M}$ $\mathrm{KCl}, 10 \mathrm{mM} \mathrm{MgCl}, 2.5 \mathrm{mM} 2$ mercaptoethanol pH 6.4. Reactions were initiated by addition of substrate after thermal equilibration of the mixture. Glyceraldehyde-3-phosphate dehydrogenase was tested as follows: buffer as above, $2.5 \mathrm{mM} \mathrm{NAD}{ }^{+}, 2.5 \mathrm{mM}$ ADP, $20 \mathrm{mM}$ $\mathrm{KH}_{2} \mathrm{PO}_{4}, 4$ units phosphoglycerate kinase and 10 units of triosephosphate isomerase. As substrate a mixture of glyceraldehyde-3phosphate and dihydroxyacetone phosphate equilibrated with triose phosphate isomerase was used. The calculations of the effective concentrations of glyceraldehyde-3-phosphate were done accepting an equilibrium constant for the reaction of $1 / 22$ (Oesper and Meyerhof, 1950).

Kinetic parameters $K_{m}$ and $V_{\max }$ were derived from linear representations using the transformation of Hofstee (Gancedo, 1974). Specific activities are expressed as units per milligram protein.

\section{Protein Determination}

In the case of the assays in situ the equivalence between yeast weight and protein is $50 \mathrm{mg}$ of extractable protein per gram fresh yeast (Serrano et al., 1973). In the case of the extracts protein was determined by the method of Lowry et al. (1951) after precipitation of the protein with $5 \%$ trichloroacetic acid. Bovine serum albumin was used as standard.

\section{Fermentation of Glucose}

Fermentation of glucose was measured in a Warburg respirometer employing $50 \mathrm{mg}$ intact or permeabilized yeast cells or an equivalent amount of protein in the case of cell free extracts. The final volume was $1 \mathrm{ml}$ and the fermentation mixture was $80 \mathrm{mM} 2$-(N-morpholino) ethane sulfonic acid, $0.1 \mathrm{M} \mathrm{KCl}, 10 \mathrm{mM} \mathrm{MgCl}, 20 \mathrm{mM} \mathrm{NH}_{4} \mathrm{Cl}$, $5 \mathrm{mM} 2$ mercaptoethanol, $0.5 \mathrm{mM}$ EDTA $\mathrm{pH} 6.4$ and the additions indicated in the corresponding figure. After $15 \mathrm{~min}$ thermal equilibration glucose was tipped from the side arm of the Warburg vessel (zero time).

Determination of metabolites in the fermentation media was carried out as described in Bergmeyer (1974) after precipitation of the permeabilized cells with perchloric acid and neutralization of the resulting supernatant.

Reagents. 2-(N-morpholino) ethane sulfonic acid was from Calbiochem (Lucerne, Switzerland), pyridine nucleotides and auxiliary enzymes were from Boehringer or Sigma. All other reagents were of analytical grade.

\section{Results and Discussion}

Kinetic Parameters

of Glycolytic Enzymes in situ versus in vitro

Table 1 shows the values obtained for the maximal velocities of the glycolytic enzymes of $S$. cerevisiae measured in situ and in vitro (cell free extracts). As it can be seen no significant differences between the two conditions are observed. The lowest value is presented by phosphofructokinase that appears as the limiting step in glycolysis.

In the same table are presented the values of $K_{m}$ or $\mathrm{S}_{0.5}$ for the different enzymes tested. The results are similar in both cases; moreover they closely agree with those found in the literature except in the case of phosphoglyceromutase where a value of $0.5 \mathrm{mM}$ is reported (Grisolía and Carreras, 1975). The slight discrepancy may be due to the different $\mathrm{pH}$ used in the assay.

The values for $S_{0.5}$ of phosphofructokinase are dependent of the conditions of assay. We measured the enzyme at a concentration of ATP that is noninhibitory $(0.1 \mathrm{mM})$, in the presence of $20 \mathrm{mM}$ $\mathrm{NH}_{4}^{+}$and absence of other added effectors. Phosphofructokinase poses an interesting problem, namely that when the enzyme is assayed at physiological concentrations of substrates and effectors its activity does not account for the glycolytic flux observed in vivo. An effect of the protein dilution in extracts could be thought to be responsible of the low activity observed (Hofer, 1971). However, the same low activity was found in situ. It has been later found that physiological activity is seen only if phosphate is added to the assay (Bañuelos et al., 1977).

In the case of glyceraldehyde-3-phosphate dehydrogenase no values of $K_{m}$ for the physiological reaction are found in the literature. We have assayed the enzyme using phosphate to obtain such values. In our assay conditions (see "Material and Methods") working with a low amount of yeast or extract, the reaction is linear with time at least for the initial $3 \mathrm{~min}$. A value of $0.06 \mathrm{mM}$ as $K_{m}$ for glyceraldehyde-3-phosphate was found. Values for the $K_{m}$ of phosphate oscillated markedly (between 1 and $10 \mathrm{mM}$ ) without a plausible explanation.

A curious behaviour was observed in the case of enolase. A biphasic Hofstee plot was obtained when the enzyme activity was assayed in situ at $10 \mathrm{mM} \mathrm{Mg}^{2+}$. However, cell free extracts tested in the same conditions gave a straight line in the representation (Fig.1). If the cells were permeabilized and then ground and extracted a situation similar to the one seen in cell free extracts prepared from intact cells was observed. Isoenzymes for enolase have been described, although their kinetic constants are not different (Pfleiderer et al., 1968). It 
Table 1. Kinetic parameters of the glycolytic enzymes from Saccharomyces cerevisae assayed in situ and in vitro. The values for $K_{m}$ or $\mathrm{S}_{0.5}$ and $V_{\max }$ were obtained assaying the enzymes as described in "Material and Methods" with the substrates indicated

\begin{tabular}{|c|c|c|c|c|c|}
\hline \multirow[t]{2}{*}{ Enzyme } & \multirow[t]{2}{*}{ Substrate } & \multicolumn{2}{|c|}{$K_{m}$ or $\mathrm{S}_{0.5}(\mathrm{mM})$} & \multicolumn{2}{|c|}{$V_{\max }($ Units $/ \mathrm{mg} \cdot$ protein $)$} \\
\hline & & in situ & in vitro & in situ & in vitro \\
\hline \multirow[t]{2}{*}{ Hexokinase (EC 2.7.1.1.) } & Glucose & 0.2 & 0.1 & \multirow[t]{2}{*}{0.7} & \multirow[t]{2}{*}{0.7} \\
\hline & ATP & 0.2 & 0.2 & & \\
\hline Glucose $\mathrm{P}$ isomerase (EC 5.3.1.9.) & Fructose-6-P & 0.25 & 0.15 & 1.2 & 1.5 \\
\hline Phosphofructokinase (EC 2.7.1.11.) & Fructose-6-P & 0.4 & 0.2 & 0.4 & 0.4 \\
\hline Aldolase (EC 4.1.2.13.) & Fructose $1,6-\mathrm{P}_{2}$ & 0.6 & 0.5 & 1.2 & 1.5 \\
\hline Triose $\mathrm{P}$ isomerase (EC 5.3.1.1.) & Dihydroxyacetone $\mathrm{P}$ & 3.0 & 3.0 & 1.4 & 2.0 \\
\hline \multirow{2}{*}{$\begin{array}{l}\text { Glyceraldehyde } 3 \mathrm{P} \text { dehydrogenase } \\
\text { (EC 1.2.1.12.) }\end{array}$} & & & & & \\
\hline & Glyceraldehyde-3-P & 0.06 & 0.06 & 2.2 & 2.2 \\
\hline \multirow[t]{2}{*}{ Phosphoglycerate kinase (EC 2.7.2.3.) } & 3-P-Glycerate & 0.3 & 0.3 & \multirow[t]{2}{*}{5.0} & \multirow[t]{2}{*}{6.0} \\
\hline & $\mathrm{ATP}$ & 0.2 & 0.1 & & \\
\hline Phosphoglyceromutase (EC 2.7.5.3.) & 3-P-Glycerate & 2.5 & 2.0 & 4.0 & 3.5 \\
\hline \multirow[t]{2}{*}{ Enolase (EC 4.2.1.11.) } & \multirow[t]{2}{*}{ 2-P-Glycerate } & 0.3 & 0.07 & 3.8 & \multirow[t]{2}{*}{4.0} \\
\hline & & 0.07 & & 1.8 & \\
\hline \multirow[t]{4}{*}{ Pyruvate kinase (EC 2.7.1.40.) } & Phosphoenolpyruvate ${ }^{a}$ & 0.3 & 0.2 & \multirow[t]{4}{*}{13.0} & \multirow[t]{4}{*}{12.0} \\
\hline & $\mathrm{ADP}^{\mathrm{a}}$ & 0.7 & 0.3 & & \\
\hline & Phosphoenolpyruvate & 3.0 & 2.0 & & \\
\hline & ADP & 1.0 & 0.6 & & \\
\hline Pyruvate decarboxylase (EC 4.1.1.1.) & Pyruvate & 3.0 & 4.0 & 2.0 & 1.7 \\
\hline Alcohol dehydrogenase (EC 1.1.1.1.) & Acetaldehyde & 0.2 & 0.3 & 1.8 & 2.0 \\
\hline
\end{tabular}

a Assayed in the presence of $1 \mathrm{mM}$ fructose $-1,6-\mathrm{P}_{2}$

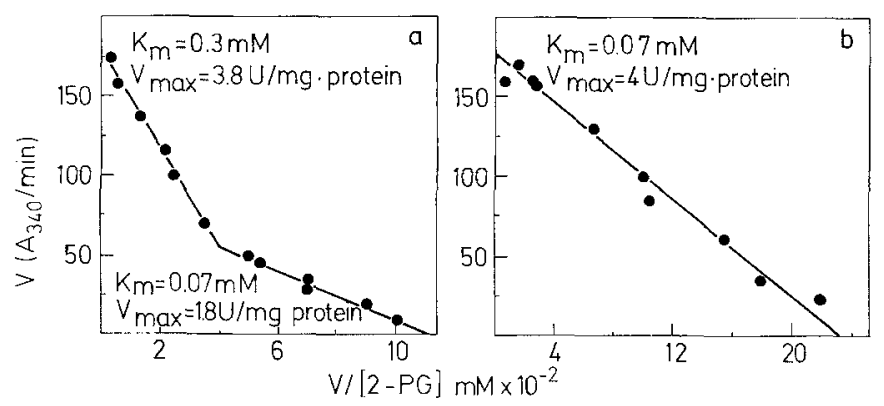

Fig. 1 a and b. Kinetic constants of enolase in situ and in vitro. The enzyme was assayed as described in "Material and Methods" in the presence of $10 \mathrm{mM}$ magnesium (a) in situ, (b) in vitro

seems therefore that the explanation of this behaviour is not the existence of isoenzymes. When the enzyme is assayed in situ at $1 \mathrm{mM} \mathrm{Mg}^{2+}$ the representation in the Hofstee plot turns linear with a $K_{m}$ of $0.1 \mathrm{mM}$ similar to the lower value obtained with $10 \mathrm{mM} \mathrm{Mg}^{2+}$. Cell free extracts in these conditions display simple kinetics with a $K_{m}$ around $0.5 \mathrm{mM}$ although dispersion of the experimental points did not allow clear cut conclusions. It would appear that enolase can exist in two forms with different affinity for 2-phosphoglycerate. The equilibrium between the forms would be affected by the concentration of magnesium in the assay and also by the protein-protein interactions. This could explain the different behaviour observed in experiments in situ and in vitro at 10 or $1 \mathrm{mM}$ magnesium.
The allosteric properties of pyruvate kinase are similar in situ and in vitro thus confirming a previous finding on this enzyme (Serrano et al., 1973).

\section{Glucose Fermentation in situ}

After having studied the behaviour of each enzyme of the glycolytic pathway it seemed worthy to examine the behaviour of the pathway working as a whole in situ and compare it with the results obtained in vitro. Permeabilized cells do not ferment glucose unless some cofactors are added. ATP, $\mathrm{NAD}^{+}$and phosphate are obligate requirements to observe fermentation (Fig. 2). Figure 3 shows the rate of fermentation in different conditions. As can be seen the rate observed in situ is intermediate between those observed in vivo and in cell free extracts. Moreover the lag phase was much more pronounced in this last case. This probably reflects the disorganization and dilution of the glycolytic machinery in the extracts. However, the pattern of the curves of evolution of $\mathrm{CO}_{2}$ is similar in situ and in vitro. Three clearly distinguishable phases are observed: an initial lag phase, a phase of maximal rate of fermentation and a phase of residual fermentation. The three phases correspond to those observed in the classical work of Harden and Young (1905) and Meyerhof (1949). The lag phase is caused most likely by the need for accumulating glycolytic intermediates to a level high enough to allow glycolysis to proceed since 


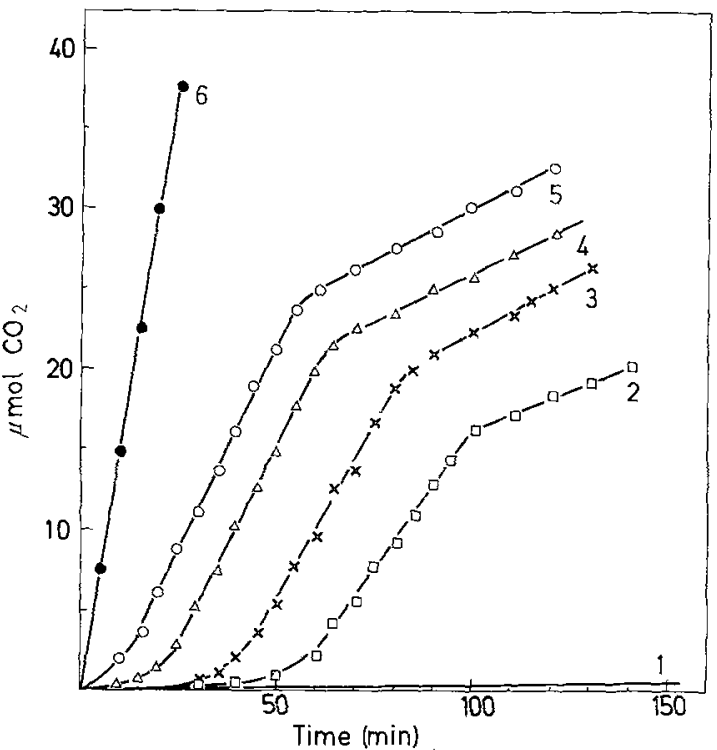

Fig. 2. Fermentation of glucose in situ. Fermentation was followed as described in "Material and Methods" with the following additions: curve $l$, none; curve $2,1 \mathrm{mM}$ ATP- $\mathrm{Mg}^{2+}, 5 \mathrm{mM} \mathrm{NAD}{ }^{+}, 10 \mathrm{mM}$ $\mathrm{KH}_{2} \mathrm{PO}_{4}$; curve 3 , same as 2 plus $0.3 \mathrm{mM}$ ADP and $0.2 \mathrm{mM} \mathrm{AMP}$; curve 4 , same as 3 plus $1 \mathrm{mM}$ NADH; curve 5 , same as 4 plus $6 \mathrm{mM}$ fructose-1,6-bisphosphate. Curve 6 was a control with the same amount of intact cells without addition. All samples received $0.1 \mathrm{M}$ glucose

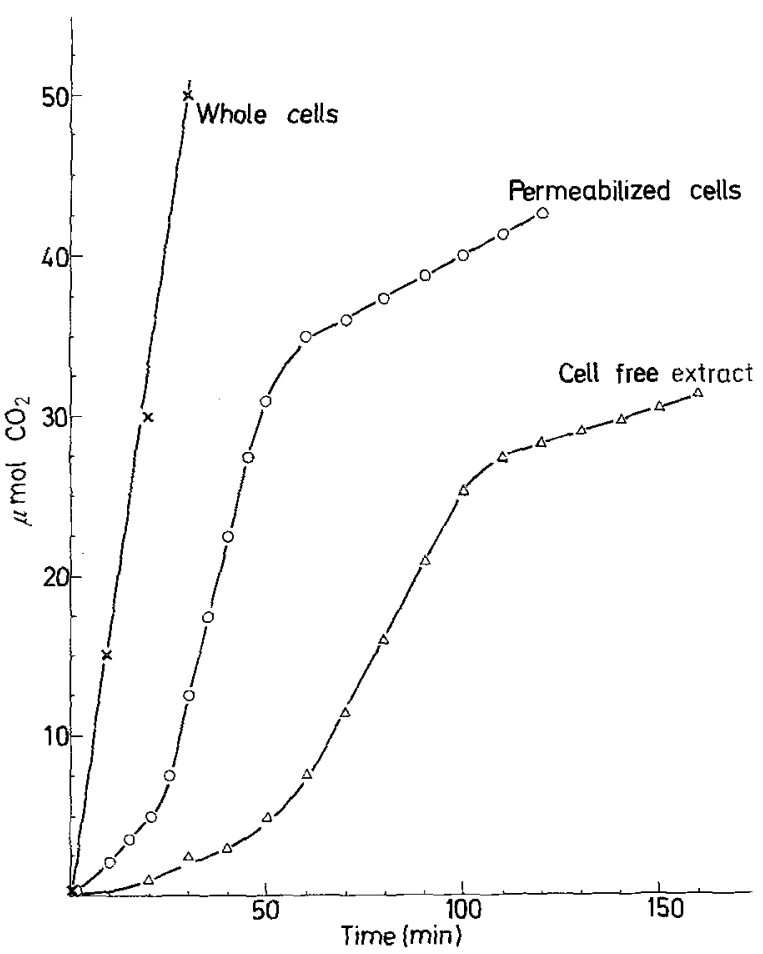

Fig. 3. Glucose fermentation by intact yeast, permeabilized yeast and cell free extracts. Fermentation was followed as described in "Material and Methods" with the following additions to the permeabilized cells and the extracts: $1 \mathrm{mM}$ ATP-Mg ${ }^{2+}, 5 \mathrm{mM}$ $\mathrm{NAD}^{+}, 0.3 \mathrm{mM}$ ADP, $0.2 \mathrm{mM}$ AMP and $1 \mathrm{mM}$ NADH. All samples contained $0.1 \mathrm{M}$ glucose and $25 \mathrm{mM} \mathrm{KH}_{2} \mathrm{PO}_{4}$

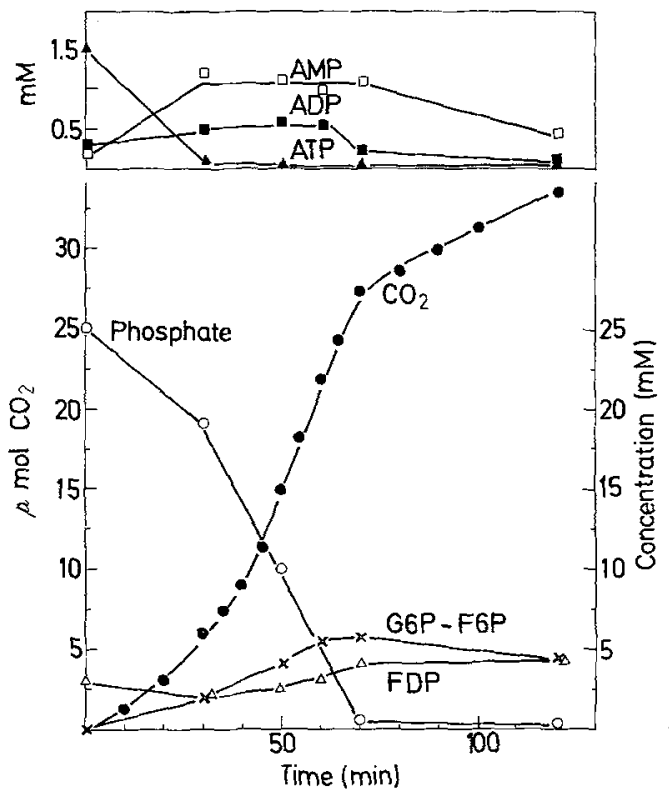

Fig. 4. Concentration of some glycolytic intermediates in fermentation mixtures of permeabilized cells. Fermentation was carried out as described in "Material and Methods" with the following additions: $0.1 \mathrm{M}$ glucose, $1.5 \mathrm{mM}$ ATP- $\mathrm{Mg}^{2+}, 0.3 \mathrm{mM}$ ADP, $0.2 \mathrm{mM}$ AMP, $5 \mathrm{mM} \mathrm{NAD}{ }^{+}, 1 \mathrm{mM}$ NADH. $3 \mathrm{mM}$ fructose-1, 6-bisphosphate, $10 \mathrm{mM} \mathrm{NH}{ }_{4} \mathrm{Cl}$ and $25 \mathrm{mM} \mathrm{KH} \mathrm{PO}_{4}$. At different times samples were taken and treated as described in "Material and Methods" to determine metabolites

addition of some compounds related to the pathway shortened the lag time as shown in Figure 2.

Accepting as equation representing glycolysis, glucose $+2 \mathrm{ADP}+2 \mathrm{Pi} \rightarrow 2$ ethanol $+2 \mathrm{CO}_{2}+2 \mathrm{ATP}$, Meyerhof (1949) accounted for the residual phase of fermentation in media where glucose was the limiting factor by assuming that during the phase of maximal velocity one molecule of glucose is phosphorylated to the stage of fructose bisphosphate with production of two molecules of ADP while another molecule is fermented to ethanol and $\mathrm{CO}_{2}$. The whole process would result in accumulation of fructose bisphosphate. When the sugar is exhausted in the medium the rate of fermentation is limited by the availability of ADP. Only if ADP is regenerated rapidly enough by some process e. g. by an ATPase, would fermentation continue at the same rate.

In our experiments the phase of residual fermentation was produced by the depletion of exogenous phosphate. Addition of phosphate (data not shown) restored the maximal velocity as in the work of Harden and Young (1905). In this case the limiting factor is clearly not ADP but phosphate itself. We measured the concentration of several metabolites in the fermentation mixture along time to see the fate of phosphate (Fig.4). As it may be seen phosphate is consumed stoichiometrically with the production of $\mathrm{CO}_{2}$ and the 
rate of disappearance is paralleled with the rate of evolution of the gas. Therefore the phosphate is consumed in glycolysis and should be accumulated in some compounds, likely in some sugar ester. Hexose monophosphates (glucose-6-P and fructose-6-P) accumulate slowly and fructose bisphosphate does not vary markedly. An increase in the initial concentration in the medium did not produce significant changes in the final levels of these esters. The sum of these esters do not account by far for the phosphate disappeared from the medium. Among the most likely destination of phosphate we consider the synthesis of polyphosphate, a process that in certain metabolic conditions is very important (Suomalainen and Oura, 1971). Consistent with this idea is the fact that the concentration of ATP decreases to very low levels with concomitant rise in ADP and AMP. Why this residual phase does not occur in vivo may not be ascertained at present. More knowledge on the enzymology and regulation of the pathway of polyphosphate synthesis and degradation (Felter and Stahl, 1973) is required to settle this point.

From our results it may be concluded that in general the behaviour observed in situ in conditions resembling those prevailing in the cell, is quite similar to that found in cell free extracts and therefore the values obtained by conventional methods may in general be used to predict the behaviour of enzymes in the cell. However, whenever protein-protein interactions may be suspected to influence the behaviour of an enzymatic system the test in situ would be a useful tool when compared with the conventional one.

Acknowledgements. Dr. Juana M. Gancedo generously helped in the preparation of the manuscript. Discussions with her and Dr. R. Serrano during the work are greatly appreciated. M. B. had a fellowship of the Spanish Ministerio de Educación y Ciencia.

\section{References}

Bañuelos, M., Gancedo, C., Gancedo, J. M.: Activation by phosphate of yeast phosphofructokinase. J. Biol. Chem. 252, 63946398 (1977)

Bergmeyer, H. U.: Methods of enzymatic analysis. Weinheim: Verlag Chemie. New York-London: Academic Press 1974

Felter, S., Stahl, A. J. C.: Enzymes du métabolisme des polyphosphates dans la levure. III. Purification et propriétés de la polyphosphate-ADP-phosphotransférase. Biochimie 55, 245251 (1973)
Frieden, C., Colman, R. F.: Glutamate dehydrogenase concentration in the effect of purine nucleotides on enzymatic activity. J. Biol. Chem. 242, 1705-1715 (1967)

Gancedo, J. M.: Determination of Michaelis constant: concentrations and linear transformations. Biochem. Educ. 2, 33 (1974)

Grisolía, S., Carreras, J.: Phosphoglycerate mutase from yeast, chicken, breast muscle and kidney. In: Methods in enzymology, Vol. XLII (V. A. Wood, ed.), pp. 435-450. New York-San Francisco-London: Academic Press 1975

Harden, A., Young, W. J.: The alcoholic ferment of yeast juice. Proc. Roy. Soc. 77B, $405-420$ (1905)

Hess, B.: Organization of glycolysis: oscillatory and stationary control. In: Rate control of biological processes. Symposia of the Society for experiment of biology, pp. 105 -131. Cambridge: Univ. Press 1973

Hess, B., Boiteux, A., Krüger, J.: Cooperation of glycolytic enzymes. In: Adv. enzyme reg., Vol. 7 (G. Weber, ed.), pp. 149-167. Oxford-London: Pergamon Press 1969

Hess, B., Boiteux, A. : Heterologous enzyme-enzyme interactions. In : Protein-protein interaction (R. Jaenicke, E. Helmreich, eds.), pp. 271-296. Berlin-Heidelberg-New York: Springer 1972

Hofer, H. W.: Influence of enzyme concentration on the kinetic behaviour of rabbit muscle phosphofructokinase. Hoppe Seyler's Z. Physiol. Chem. 352, 997 - 1004 (1971)

Hulme, E. C., Tipton, K. F.: The dependence of phosphofructokinase kinetics upon protein concentration. FEBS Letters 12, 197-200 (1971)

Kornberg, H. L., Reeves, R. E.: Correlation between hexose transport and phosphotransferase activity in Escherichia coli. Biochem. J. 126, 1241 - 1243 (1972)

Lowry, O. H., Rosebrough, N. J., Farr, A. L., Randall, R. J.: Protein measurement with the Folin phenol reagent. J. Biol. Chem. 193, $265-275$ (1951)

Meyerhof, $\mathrm{O}$.: Further studies of the Harden-Young effect in alcoholic fermentation of yeast preparations. J. Biol. Chem. 180, $575-586$ (1949)

Oesper, P., Meyerhof, O.: The determination of triose phosphate isomerase. Arch. Biochem. Biophys. 27, 223-233 (1950)

Olson, B. H., Johnson, M. J.: Factors producing high yeast yields in synthetic media. J. Bacteriol. 57, 235-246 (1949)

Pfleiderer, G., Neufahr-Kreiling, A., Kaplan, R. W., Fortnagel, P.: Biochemical, immunological, and genetic investigations of the multiple forms of yeast enolase. Ann. N.Y. Acad. Sci. 151, $78-$ 84 (1968)

Reeves, R. E., Sols, A.: Regulation of Escherichia coli phosphofructokinase in situ. Biochem. Biophys. Res. Commun. 50, 459-466 (1973)

Serrano, R., Gancedo, J. M., Gancedo, C.: Assay of yeast enzymes "in situ". A potential tool in regulation studies. Eur. J. Biochem. 34, 479-482 (1973)

Srere, P.: Enzyme concentrations in tissues. Science 158, 936-937 (1967)

Suomalainen, H., Oura, E.: Yeast nutrition and solute uptake. In: The yeast, Vol. 2 (A. H. Rose, J. S. Harrison, eds.), pp. 3-74. New York-London: Academic Press 1971

Received November 18, 1977 